Emilio Herrera Molina ${ }^{1,2}$, Yaneth Marcela Montoya Jaramillo³, Zacarías Rodriguez ÁlvarezOssorio', Ana Carolina Gñomez García', Miguel Ángel Lucas Díaz', Irma María Echeverri Rincón, Ingrid Muñoz Mayorga', María Nabal Vicuña ${ }^{4}$

${ }^{1}$ New Health Foundation, Sevilla, Spain

${ }^{2}$ Keralty, Miami, United States

${ }^{3}$ EPS and Medicina prepagada Suramericana SA., Medellín, Colombia

${ }^{4}$ Palliative care team. Arnau de Villanova Hospital, Lleida, Spain

\title{
Health care services utilization and cost in the last year of life in Colombia: a retrospective study
}

\section{Abstract}

Introduction: Health care costs at the end of life cause a high expenditure on health care resources. The implementation of integrated palliative care programs has proven to be cost-efficient. The study aimed to analyze the consumption and cost of health care resources during the last year of life of patients who are not part of a palliative care program.

Methods: A descriptive, longitudinal and retrospective study was conducted in patients of a Colombian health insurance company who died in 2013 due to pathologies that were susceptible and non-susceptible to palliative care. Causes of death were obtained from official death certificates. McNamara et al. strategy of classification was applied and adapted to assess services received during the last year of life. Analysis of costs was conducted by pathologies at different levels of care.

Results: 3,392 deaths in 2013 (70\% susceptible to palliative care and 30\% non-susceptible to palliative care). Total health care cost: USD $47,550,155$. Patients susceptible to palliative care were responsible for $84 \%$ of the year's expenditure (the annual expenditure) (USD 40 million). There were significant differences between the average costs for susceptible and non-susceptible palliative care patients (USD 16,878 versus USD 7,433 per year, $p<0.001$ ). The average cost per patient for the last three months of life represented $52 \%$ of the expenditure during the last year of life (USD 8,754). The last month of life was $25.6 \%$ of the expenditure during the last year of life (USD 4,324).

Conclusions: Cost of care for the last three months of life of susceptible palliative care patients generates a huge health care expenditure, mainly attributable to hospital care cost. The implementation of a palliative care program could decrease these assistance costs.

Palliat Med Pract 2021; 15, 1: 9-17

Key words: palliative care, cause of death, population, cost-benefits analysis, models

Address for correspondence:

Emilio Herrera Molina

New Health Foundation

Menendez Pelayo Av, 20. 4 41004 Sevilla, Spain

e-mail: emilio.herrera@newhealthfoundation.org

Palliative Medicine in Practice 2021; 15, 1, 9-17

Copyright (c) Via Medica, ISSN 2545-0425

DOI: $10.5603 / \mathrm{PMPI} .2021 .0004$

This article is available in open access under Creative Common Attribution-Non-Commercial-No Derivatives 4.0 International (CC BY-NC-ND 4.0) license, allowing to download articles and share them with others as long as they credit the authors and the publisher, but without permission to change them in any way or use them commercially. 


\section{Introduction}

The current global population trends are generating higher life expectancy levels; an increase in the prevalence of chronic diseases [1], which are creating unprecedented financial pressure on health systems $[2,3]$, which will be unsustainable in a short term. Almost $70 \%$ of the population dies every year due to advanced illness caused by either cancer $(2,500$ cases per million people) or non-cancer diseases $(4,500 \mathrm{ca}$ ses per million people) [4]. However, despite the international acknowledgement of such a situation and the existence of national [5] and international $[6,7]$ policies, palliative care coverage hardly reaches up to $14 \%$ of the world's population [8]. The lack of palliative care models causes an unsustainable increase of the health care costs and poor quality in the care of patients [9] (inadequate symptom control, pain relief [10], hospital deaths [11], lack of communication with the patients' families and family support [12]).

One of the highest cost in health care is associated with cancer care in the last year of life [13], with a total of USD 205 billion in the USA for serious illness (13\% of the total expenditure) [14], where patients with chronic diseases generate the $57 \%$ of the total cost (USD 44,220 per person per year) [15]. The last six months of life concentrate $40 \%$ of the total health expenditure [16], it is in the last three months when the increase is most significant [17]. For cancer, patients of a Spanish region cost up to $€ 12,034$ per person in the last year of life [18] whereas, if only hospital costs per person are considered, these are USD 21,840 in Canada, USD 18,500 in the USA and USD 9,342 in England [19].

The poor development of palliative care is the result of the lack of awareness of health policymakers and managers of the expenditures that derive from not having implemented palliative care services. In order to adopt newly integrated and cost-effective palliative care models $[20,21]$ that could respond to the needs of people at the end of life, the first step is to analyze the assistance the population receives at the end of life without palliative care programs and the cost that this assistance generates to the health services [22]. This study aims to identify and measure the utilization and cost of health care resources used by patients affiliated to a Colombia health insurance company (Suramericana S.A.) before the implementation of a palliative care program to estimate the need to develop a palliative care program. For such purpose, the NewPalex ${ }^{\circledR}$ method [23] has been used to achieve palliative care excellence within the organisation.

\section{Methods}

\section{Study design and population}

A descriptive longitudinal and retrospective study was conducted to evaluate the need for the implementation of a palliative care program in Suramericana S.A. company. People who died in 2013 were identified and classified as susceptible and non-susceptible for palliative care. Understanding as susceptible for palliative care, those people with an advanced, incurable, and progressive disease either oncologic or non-oncologic without reasonable possibilities to respond to the specific treatment, progressive deterioration, with a limited life forecast whom should have been assessed by a palliative care service and/or with McNamara [24] criteria; identified with the IDC10 criteria. Classified in: oncology, chronic obstructive pulmonary disease (COPD) and cardiac failure, neurodegenerative diseases (amyotrophic lateral sclerosis, motor neuron disease, Parkinson, Huntington and Alzheimer), kidney failure and other (liver failure and HIV-AIDS). Diabetes was also included, given that it is one of the main causes of death in Colombia [25].

Deaths were identified from Suramericana S.A. databases. Mortality causes were obtained - in the $78 \%$ of the cases - from the official death certificates registered according to the international diseases classification ICD-10. When certificates were not available, we analyzed the hospital admissions, outpatient specialist visits and diagnostic test results activities from health care providing institutions during the last year of life to identify the cause of death.

\section{Variables}

Services were classified by months, levels of care and common services:

1. Level III - hospital

- High cost: related to high-cost events in care: transplants, and cancer treatment.

- Surgery

- Hospitalization

- Emergency.

2. Level II - outpatient

- Outpatient medical visits.

3. Level I - home

- Home care.

4. Common services: endoscopies, consumptions/ medical supplies, drugs, miscellaneous, diagnostic tests and therapies.

The analysis included all health care interventions registered in the health insurance company's information system in the last 12 months of life. Costs were attributed to each intervention corresponding to the value paid by activity. Values were converted 
into American dollars (exchange rate USD $1=$ COP 1,884.97).

\section{Statistical analysis}

The statistical analysis was conducted with IBM SPSS ${ }^{\circledR}$ statistical database to obtain frequencies, percentages and Student's $s$-test in order to compare the average costs between susceptible and non-susceptible palliative care patients.

\section{Results}

In 2013, there were 3,392 deaths. $70 \%$ $(2,365$ deaths) was susceptible to palliative care and $30 \%(1,027$ deaths) was non-susceptible for palliative care.

\section{Susceptible and non-susceptible palliative care}

Cancer was the most frequent cause of death in susceptible palliative care $(43.6 \%)$, followed by COPD (22.6\%) and diabetes (13.1\%) (Table 1). The total cost of care at the end of life was USD 47,5 million. Susceptible palliative care represented $84 \%$ of the total cost (USD 40 million per year). Susceptible palliative care patients deaths had an average cost per person of 2.3 times higher than non-susceptible palliative care (USD 16,878 versus USD 7,433 per year, $\mathrm{p}<0.001$ ) (Table 1). Cancer (USD 20,820), followed by HIV/liver failure (USD 18,672), kidney failure (USD 18,626) and cardiac failure (USD 17,036) had an average cost per person above that the overall population of deceased patients (USD 14,018) (Table 1).
The cost of the last three months of life was $52 \%$ (USD 8,754 average cost) of the annual cost for susceptible palliative care (Table 2 ). Care in the last month of life had a higher cost than the average of the total susceptible palliative care patients deaths (USD 4,324): HIV/liver failure (USD 6,739), kidney failure (USD 5,228), cancer (USD 4,633), diabetes (USD 4,456) and cardiac failure (USD 4,150) (Table 2). The evolution of the average cost per person during the last year of life in susceptible and non-susceptible palliative care patients is represented in Figure 1.

\section{Levels of care}

Level III-hospital accounted for $56 \%$ of the annual cost for susceptible palliative care, which is two times higher than non-susceptible palliative care (USD 9,445 vs. USD 5,401 average cost per year). Hospital inpatient, high cost and surgery were responsible for $24.3 \%, 15.6 \%$, and $14.2 \%$ of the annual cost for susceptible palliative care (Table 3 ). The evolution of the average cost per person in susceptible palliative care patients with the highest cost during the last year of life is represented in Figure 2.

The hospital costs of the three last months of life were $17 \%$ of the annual cost for susceptible palliative care. The average cost per person was USD 436 in the three last months of life and USD 1,670 in the last month of life. In the last month of life, hospitalization corresponded to the $38.6 \%$ (USD 1,670 average cost per year), followed by surgery (15.1\%), drugs (13.6\%), high cost $(10.8 \%)$, miscellaneous $(5.0 \%)$, diagnostic procedures (4.1\%) (Table 3).

At the level II outpatient, the average cost per year in susceptible palliative care deaths was three times hi-

Table 1. EPS Sura's insured population dead in 2013. The total and average cost per person in the last 12 months of life (Susceptible Palliative Care versus Non-Susceptible Palliative Care)

\begin{tabular}{lllll} 
& Population & $\%$ & Total Cost (USD\$)/\% & Average Cost (USD\$) \\
\hline Total deaths & $\mathbf{3 , 3 9 2}$ & $\mathbf{1 0 0 \%}$ & $\mathbf{\$ 4 7 , 5 5 0 , 1 5 5}$ & $\mathbf{\$ 1 4 , 0 1 8}$ \\
\hline Total NSCP & $\mathbf{1 , 0 2 7}$ & $\mathbf{3 0 . 3 \%}$ & $\mathbf{7 , 6 3 3 , 6 4 2 ( 1 6 \% )}$ & $\mathbf{7 , 4 3 3}(*)$ \\
\hline Total SCP & $\mathbf{2 , 3 6 5}$ & $\mathbf{6 9 . 7 \%}$ & $\mathbf{3 9 . 9 1 6 . 5 1 2 ( 8 4 \% )}$ & $\mathbf{1 6 , 8 7 8 ( ^ { * } )}$ \\
\hline Cancer & 1,032 & $43.6 \%$ & $21,486,336(45.2 \%)$ & 20,820 \\
\hline Other $($ VIH, liver failure) & 28 & $1.2 \%$ & $\$ 522,820(1.1 \%)$ & 18,672 \\
\hline Kideny failure & 216 & $9.1 \%$ & $4,023,313(8.5 \%)$ & 18,626 \\
\hline Cardiac failure & 166 & $7.0 \%$ & $2,827,970(5.9 \%)$ & 17,036 \\
\hline Diabetes & 309 & $13.1 \%$ & $4,018,491(8.5 \%)$ & 13,005 \\
\hline COPD & 534 & $22.6 \%$ & $6,536,101(13.7 \%)$ & 12,240 \\
\hline Nuerodegenerative disease & 80 & $3.4 \%$ & $\$ 501,480(1.1 \%)$ & 6,269
\end{tabular}

(*) Student's t-statistic $p=0.000$ There are significant differences between the average costs of Susceptible Palliative Care and Non-Susceptible Palliative Care patients. 


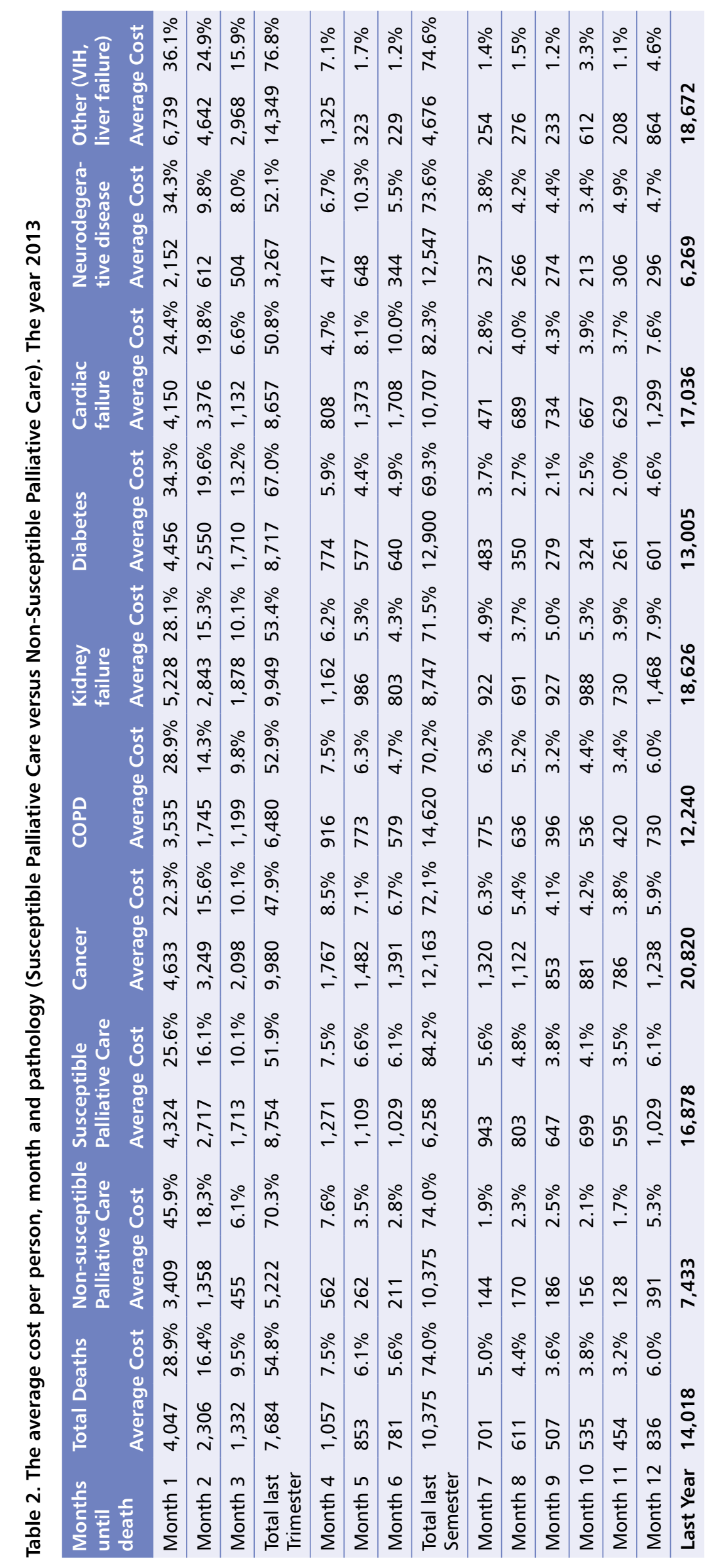



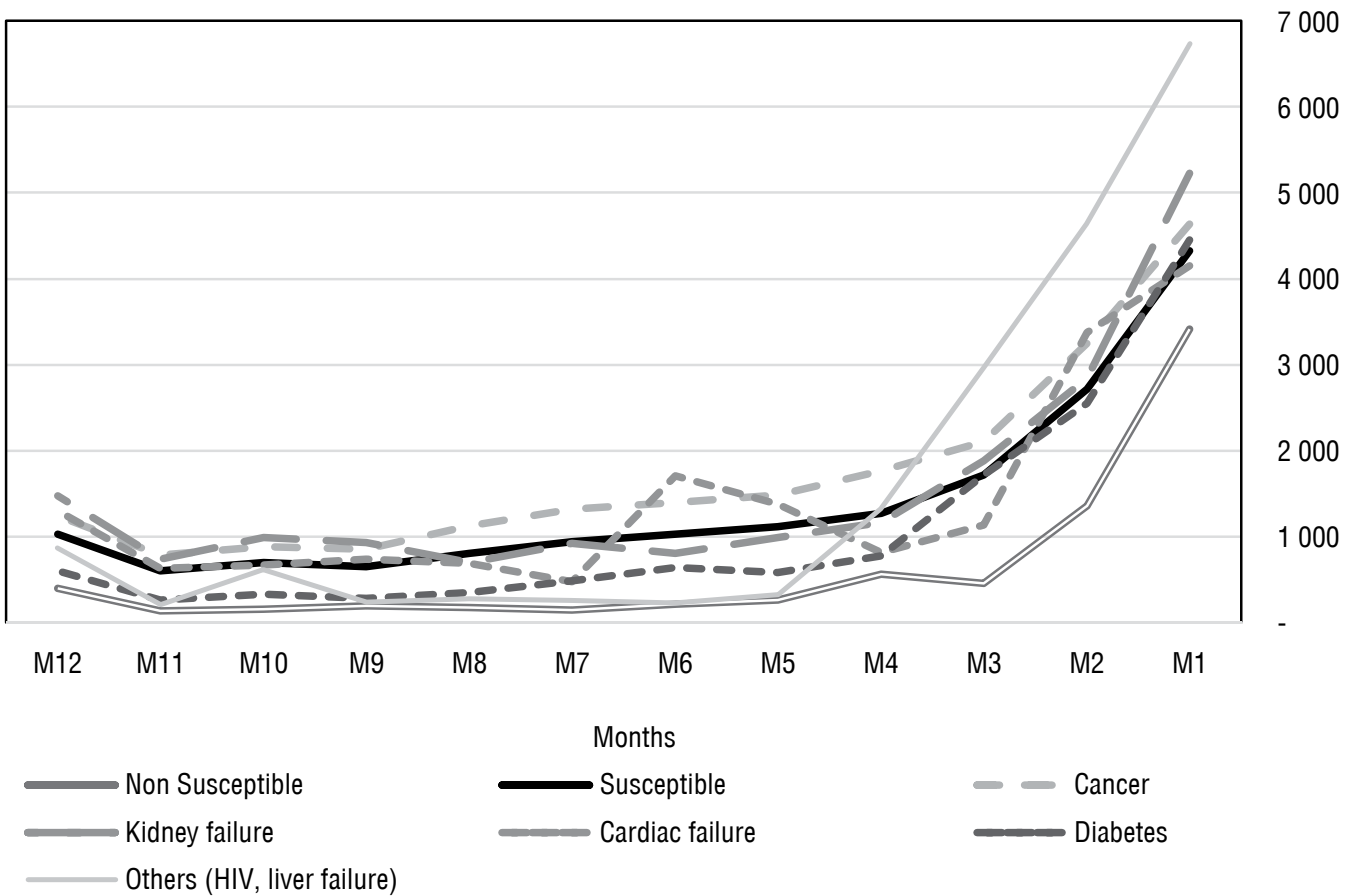

Figure 1. Evolution of the average cost (USD\$) per person during the last year of life (Susceptible Palliative Care versus Non-Susceptible Palliative Care). The year 2013

gher than non-susceptible palliative care deaths (USD 107 vs. USD 35). The average cost per year at the level-I home is 3.5 times higher in susceptible palliative care deceased patients compared to non-susceptible palliative care deceased patients (USD 575 vs. USD 165). Common services accounted for $40 \%$ of the cost being drugs responsible for $23.2 \%$ of the average cost per year (Table 3).

\section{Discussion}

The costs of end-of-life of 2.5 million insured people have been calculated in USD 47.5 million, with data from 2013. Susceptible palliative care patients are responsible for $84 \%$ of this expenditure, coming up to USD 40 million. This cost is linked to the proportional increase in each of the different type of services, which increases during the last year of life. This study has shown that the lack of a palliative care program in patients susceptible to receive palliative care significantly enhances the costs in the last three months of life, being responsible for the $44 \%$ of the total cost of the people who died (USD 20 million/USD 8,754 average cost per year).

Costs in the final year of life have been calculated in USD 205 billion in the USA [2] and USD 4.7 billion in Canada [21]. In Colombia, the expenditure over the last three months of life was $50 \%$ of the total health care cost of the last year of life [26]. Inpatient hospitalization generates the highest cost during the last month, is estimated at 67\% in Canada [27], 59\% in Ireland [28], $f 585$ million for susceptible palliative care patients in the United Kingdom [29].

Moreover, we want to highlight the usefulness of the NewPalex ${ }^{\circledR}$ methodology to identify susceptible palliative care patients in the health information systems, by finding the causes of death and the interventions conducted during the last year of life. ICD-10 codes are compared with the McNamara et al. [24] criteria for defining and estimating the palliative care population. From this, it is possible to evaluate costs at the end-of-life in a systematic and replicable process. Consequently, a baseline analysis can be conducted and be used as the first step to implement palliative care programs, with clear objectives and priorities to guide the intervention and to evaluate the economic, clinical and service quality impact.

This type of analysis allows both public and private insurers to acknowledge the cost impact that derives from not having a palliative care program implemented. The lack of such evaluations in a systematic way has contributed to the limited implementation of palliative care programs in contemporary health systems despite their importance and even the programmatic commitment of some countries to provide this kind of services. 


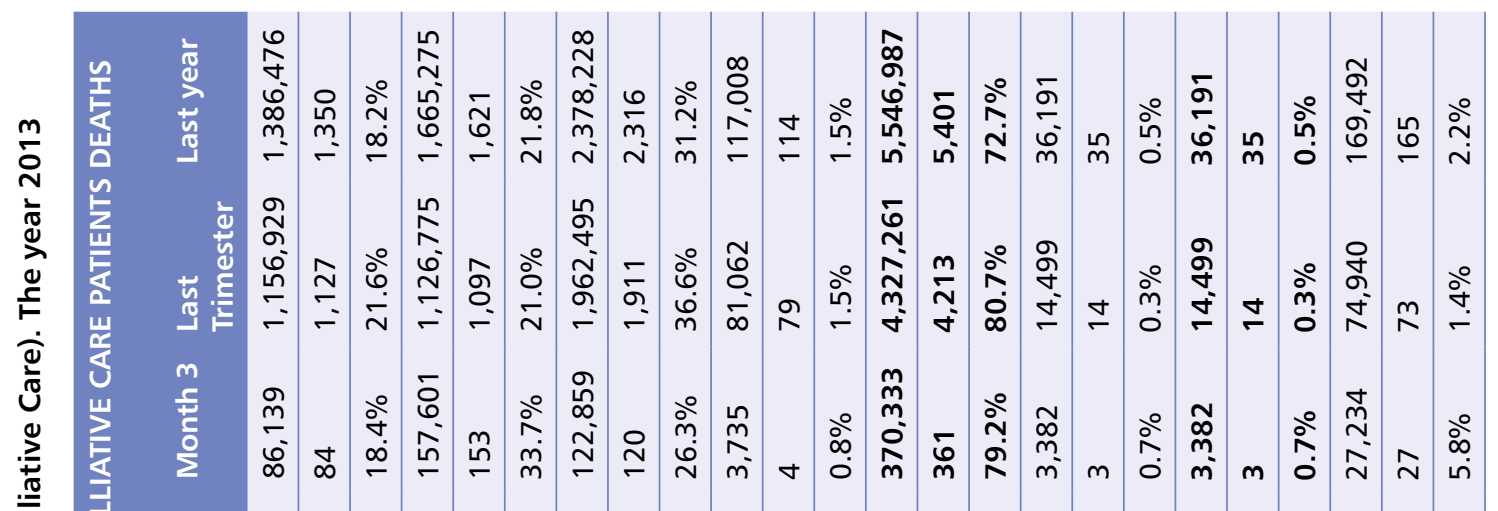

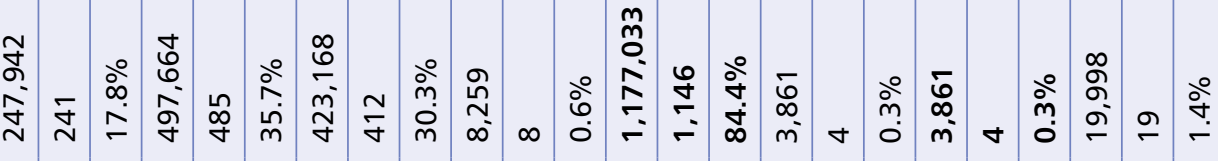

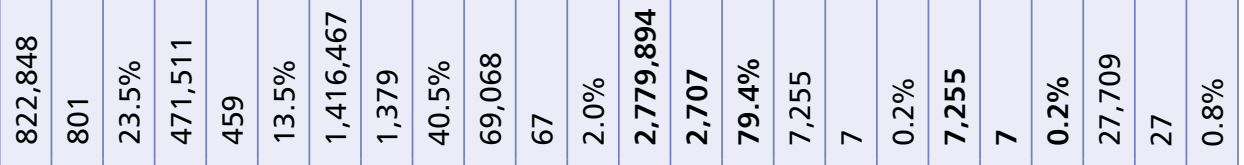

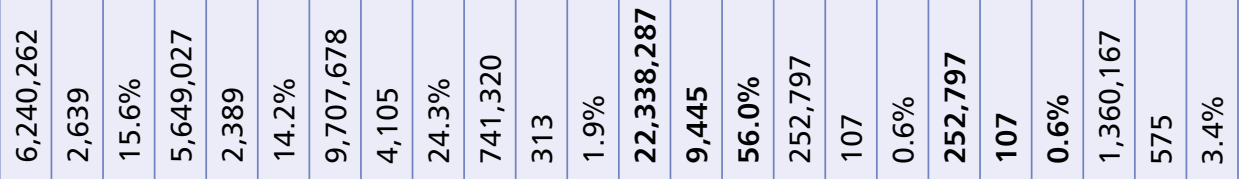
$\stackrel{0}{\circ}$

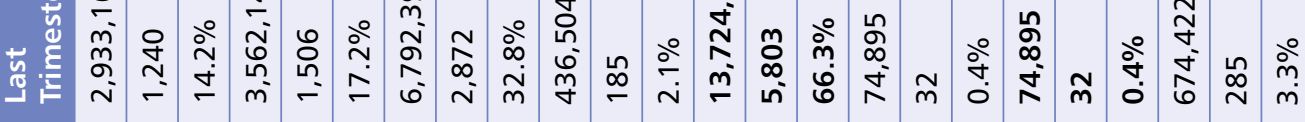

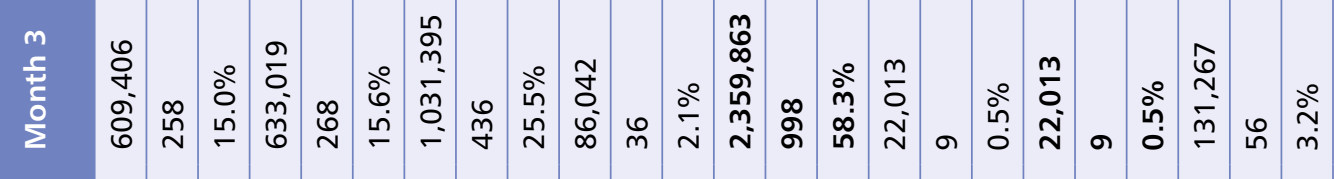

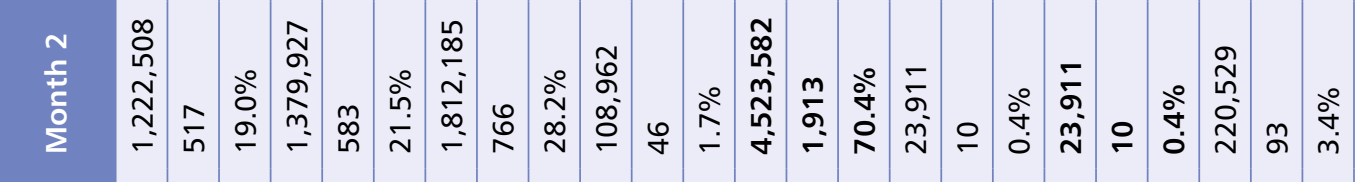

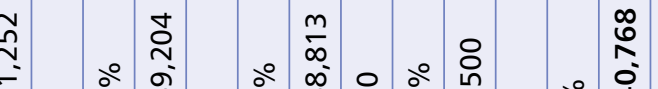

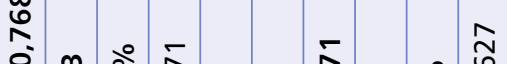

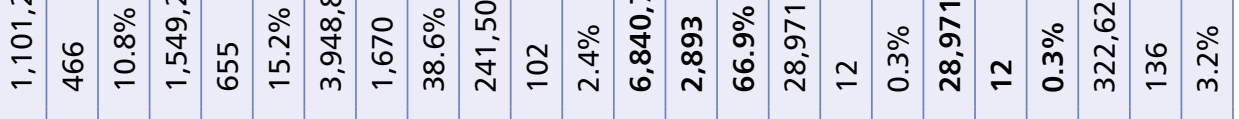

4

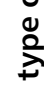

$\frac{\sqrt{2}}{\mathfrak{c}^{\frac{1}{2}}}$

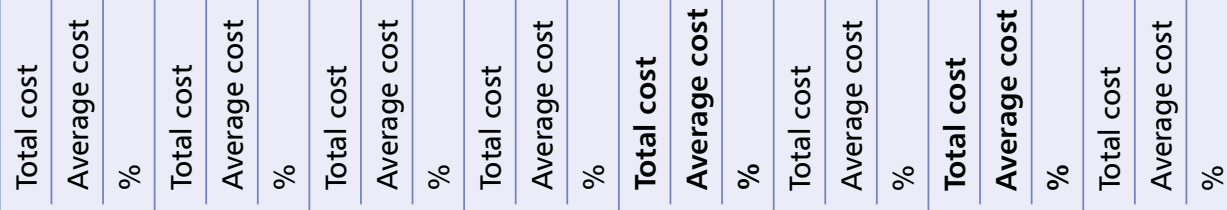

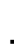

$\frac{\sqrt{2}}{\frac{2}{2}}$ 


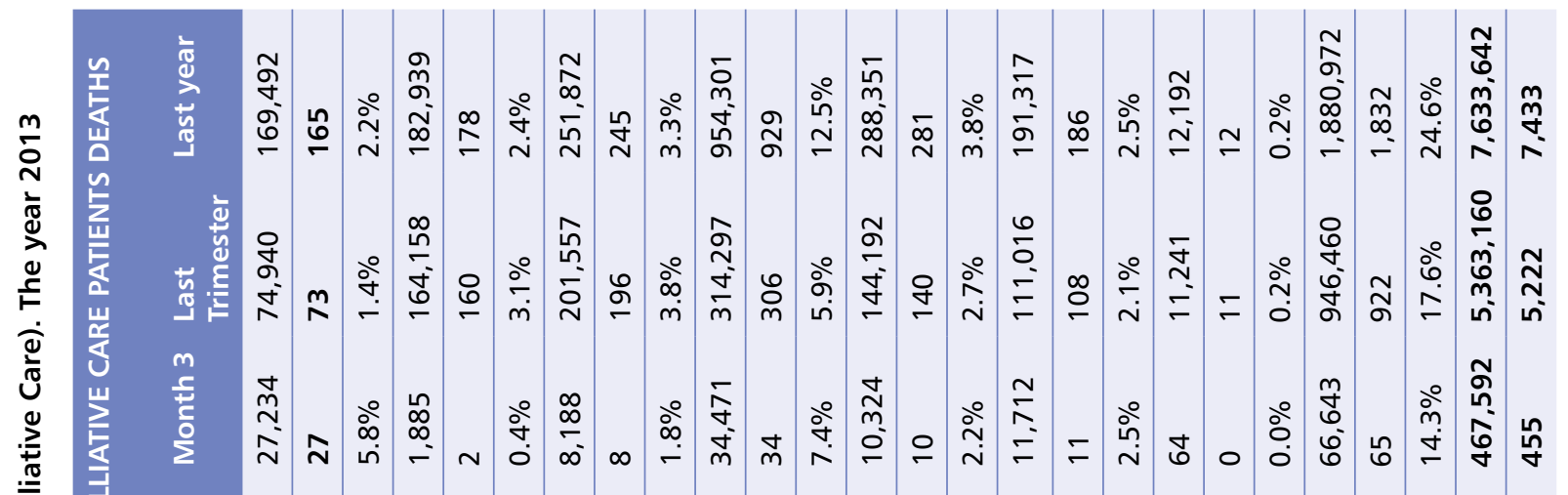

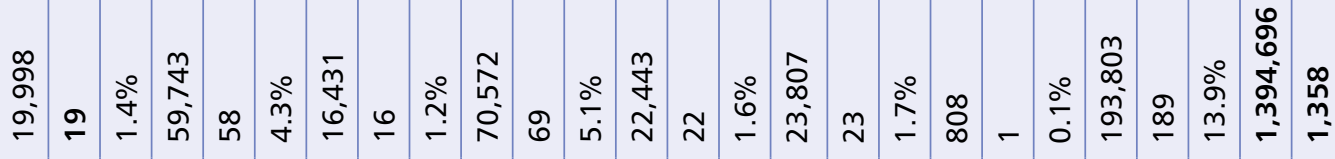

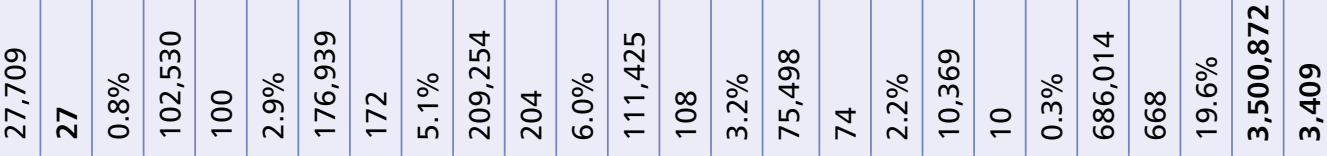

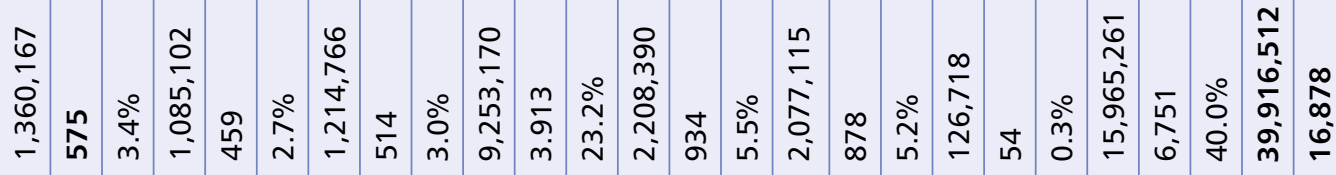

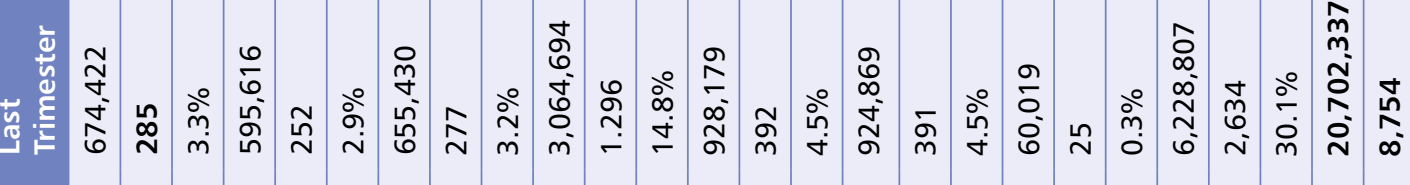

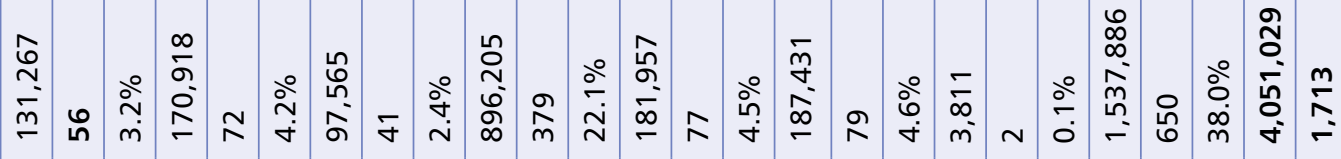

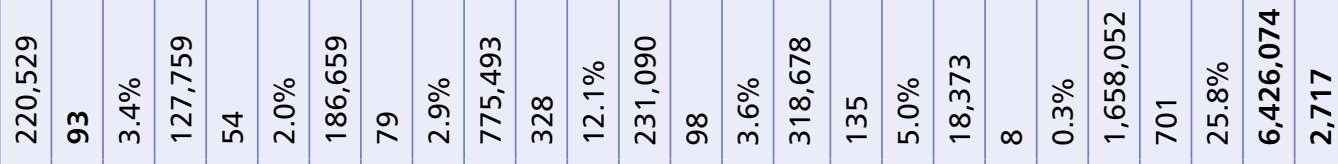

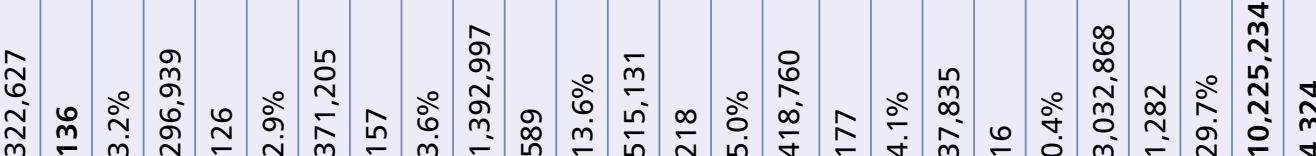

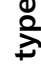

官

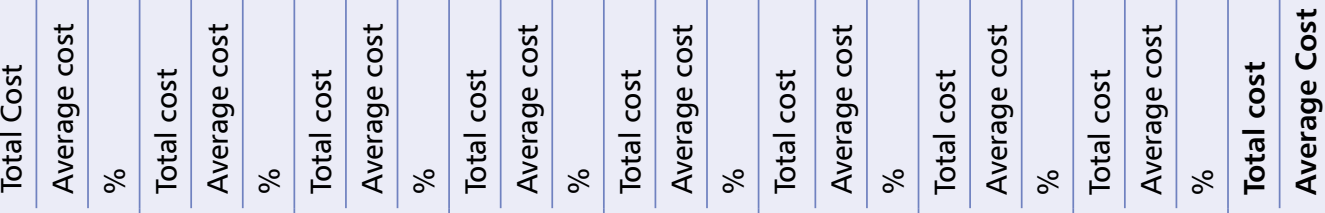

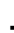

党
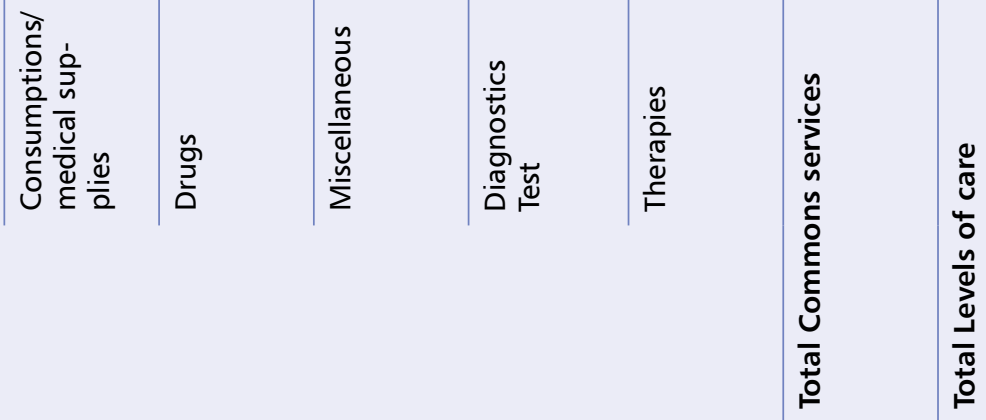


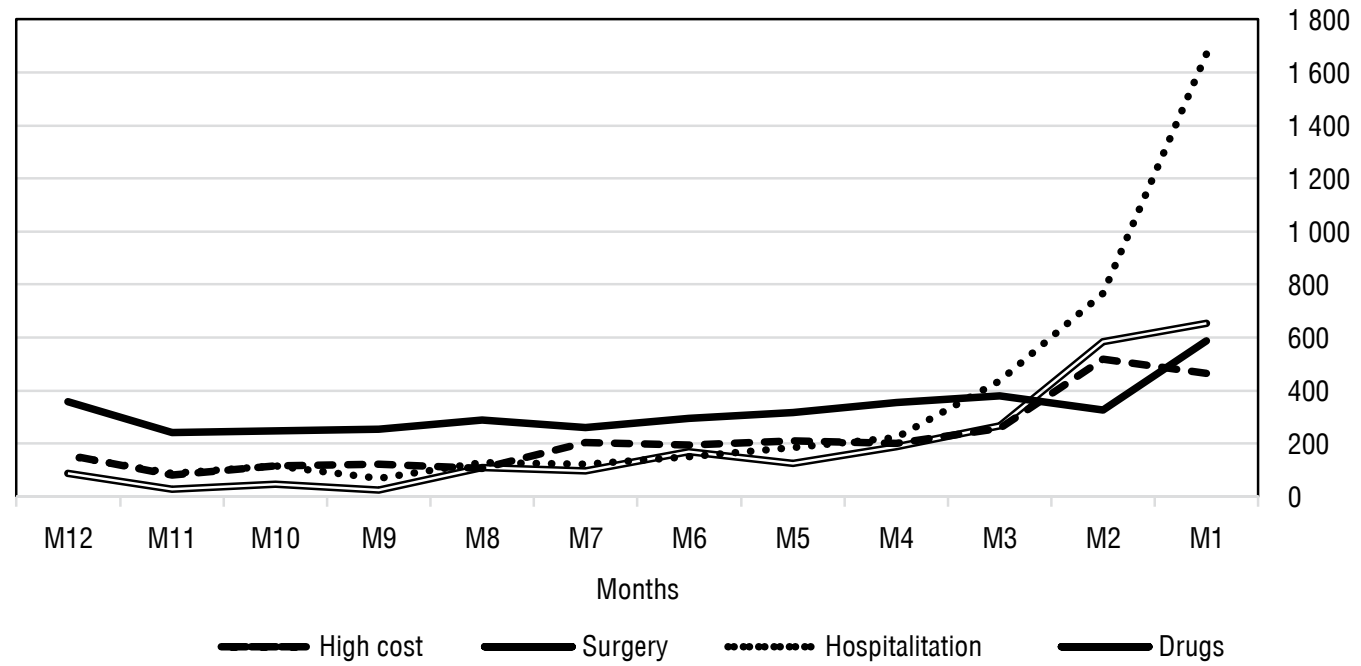

Palliative care offers the best contribution to humanized and integrated care for patients that is cost-effective. After this study, a palliative care program was implemented in the organization according to the NewPalex methodology in the period between 2014 and 2018. A comparative study was conducted among patients who entered the program with those who did not and the results were compared with those made in this initial study, reaching the same conclusions as those extracted in this article that allowed us to corroborate all these data, and this is the reason why conclusions are still relevant 6 years later. Palliative care programs should be systematically developed by health care organizations as they allow for the provision of efficient, compassionate and appropriate care while contributing to the sustainability of health systems.

\section{Limitations}

Despite the studied population covers all people who died insured by a health insurance company of approximately 2.5 million affiliates, they however belong to the contributive insurance regime. Therefore, it does not exactly represent a global sample of the Colombian people which would require to include people insured under the subsidized scheme. Similarly, the quantitative value had limitations that ask for caution to be generalized, because the results reflect the prices agreed between the insurance company and the health providers, and can therefore vary for other insurance companies or in different contractual arrangements.
A third limitation relates to the quality of the data used because it is a retrospective study, with $22 \%$ of all causes not having been identified in the death registries. Thus, several care interventions may have been left out, which may be important to identify the causes and the subsequent costs. It is considered, however, to be a necessary starting point to assess the extent of the program which in turn will be of great usefulness to compare the costs prospectively for groups of patients with and without integrated palliative care systems.

\section{Conclusions}

The study allows concluding that the assessment of the care costs at the end-of-life is a valuable management tool for insurance companies as well as for service managers and health policymakers. As demonstrated the cost increases in the last months of life of susceptible palliative care patients who do not receive palliative care. A caring approach to the end-of-life, which would not include palliative care results in considerable cost impact in the last three months. Such an approach is responsible for a great deal of the annual total health care expenditure, largely deriving from hospital care and aggressive and high-cost procedures.

\section{Declaration of conflict of interests}

The authors declare that there is no conflict of interest.

\section{Funding}

None declared. 


\section{References}

1. World Health Organization. Projections of mortality and causes of death, 2015 and 2030. Geneva 2015.

2. Aldridge MD, Kelley AS. The Myth Regarding the High Cost of End-of-Life Care. Am J Public Health. 2015; 105(12): 2411-2415, doi: 10.2105/AJPH.2015.302889, indexed in Pubmed: 26469646.

3. Martos F, Herrera E, Espín J, et al. Socioeconomic implications. In: Jadad AR, Cabrera A, Smith R, Lyons RF. editors). When people live with multiple chronic diseases: a collaborative aroach to an emerging global challenge. Granada: Andalusian School of Public Health. 2010: 211-227.

4. Franks PJ, Salisbury C, Bosanquet N, et al. The level of need for palliative care: a systematic review of the literature. Palliat Med. 2000; 14(2): 93-104, doi: 10.1191/026921600669997774, indexed in Pubmed: 10829143.

5. Congress of the republic. Consuelo Devis Saavedra Law; Official Gazette No. 49, 268. September 8, 2014. Constitutional Court. Law 1733 of 2014. Bogot 2014.

6. Recommendation Rec 24 of the Committee of Ministers of the member states on palliative care organization. Madrid: Quality Agency of the National Health System. Ministry of Health. 2003; 2005.

7. Schmidlin E, Oliver D. Palliative care as a human right: What has the Prague Charter achieved? Eur J Palliat Care. 2015; 22(3): 141-143.

8. World Health Organization. Palliative care: Key facts. http:// www.who.int/mediacentre/factsheets/fs402/es/ (9 September 2019).

9. The 2015 Quality of Death Index: Ranking palliative care across the world. The Economist Inteligence Unit Limited 2015. https://eiuperspectives.economist.com/sites/default/files/2015\%20EIU\%20Quality\%20of\%20Death\%20 Index\%200ct\%2029\%20FINAL.pdf/ (25 August 2019).

10. Solano JP, Gomes B, Higginson IJ. A comparison of symptom prevalence in far advanced cancer, AIDS, heart disease, chronic obstructive pulmonary disease and renal disease. J Pain Symptom Manage. 2006; 31(1): 58-69, doi: 10.1016/j. jpainsymman.2005.06.007, indexed in Pubmed: 16442483.

11. Khandelwal N, Curtis JR, Freedman VA, et al. How Often Is End-of-Life Care in the United States Inconsistent with Patients' Goals of Care? J Palliat Med. 2017; 20(12): 1400-1404, doi: 10.1089/jpm.2017.0065, indexed in Pubmed: 28665781.

12. Hudson PL, Aranda S, Kristjanson $\amalg$. Meeting the supportive needs of family caregivers in palliative care: challenges for health professionals. J Palliat Med. 2004; 7(1): 19-25, doi: 10.1089/109662104322737214, indexed in Pubmed: 15008126.

13. Chastek B, Harley C, Kallich J, et al. Health care costs for patients with cancer at the end of life. J Oncol Pract. 2012; 8(6): 75s-80s, doi: 10.1200/JOP.2011.000469, indexed in Pubmed: 23598848.

14. Committee on Approaching Death: Addressing Key End of Life Issues; Institute of Medicine. Dying in America: Improving Quality and Honoring Individual Preferences Near the End of Life. Washington (DC): National Academies Press (US); 2015 Mar 19. Appendix E, Epidemiology of Serious Illness and High Utilization of Health Care. https://www. ncbi.nlm.nih.gov/books/NBK285684/ (20 August 2019).

15. Meier DE. Increased access to palliative care and hospice services: opportunities to improve value in health care. Milbank Q. 2011; 89(3): 343-380, doi: 10.1111/j. 1468-0009.2011.00632.x, indexed in Pubmed: 21933272.
16. May P, Garrido MM, Cassel JB, et al. Palliative Care Teams' Cost-Saving Effect Is Larger For Cancer Patients With Higher Numbers Of Comorbidities. Health Aff (Millwood). 2016; 35(1): 44-53, doi: 10.1377/hlthaff.2015.0752, indexed in Pubmed: 26733700.

17. Nuño-Solinís R, Herrera Molina E, Librada Flores $S$, et al. [Care costs and activity in the last three months of life of cancer patients who died in the Basque Country (Spain)]. Gac Sanit. 2017; 31(6): 524-530, doi: 10.1016/j.gaceta.2016.06.005, indexed in Pubmed: 27707518.

18. Librada S, Herrera E, Nuño R. Consumption of health resources and costs of end-of-life care for 18, 024 people killed by cancer in the Basque Country between 2008 and 2011. X Congress of the Spanish Palliative Care Society, Madrid 2014.

19. Bekelman JE, Halpern SD, Blankart CR, et al. International Consortium for End-of-Life Research (ICELR). Comparison of Site of Death, Health Care Utilization, and Hospital Expenditures for Patients Dying With Cancer in 7 Developed Countries. JAMA. 2016; 315(3): 272-283, doi: 10.1001/jama.2015.18603, indexed in Pubmed: 26784775.

20. Librada S, Herrera E, Nabal M. et al. Implementation models of cities and compassionate communities around people with advanced diseases and/or end of life situations: a systematic review. PROSPERO 2017: CRD42017068501. https:// www.crd.york.ac.uk/prospero/display_record.php? ID =CRD42017068501/ (24 July 2019).

21. Librada S, Herrera E, Pastrana T. Attention centered on the person at the end of life: Integrated socio-health care in palliative care. Actas de la coordinación sociosanitaria. 2015; 13: 67.

22. Tanuseputro $P$, Wodchis WP, Fowler $R$, et al. The health care cost of dying: a population-based retrospective cohort study of the last year of life in Ontario, Canada. PLoS One. 2015; 10(3): e0121759, doi: 10.1371/journal. pone.0121759, indexed in Pubmed: 25811195.

23. Herrera E, Librada S, Lucas MA, et al. The New Health Foundation: Transforming palliative care. Eur J Palliat Care. 2017; 24(3).

24. McNamara B, Rosenwax LK, Holman CD. A method for defining and estimating the palliative care population. J Pain Symptom Manage. 2006; 32(1): 5-12, doi: 10.1016/j.jpainsymman.2005.12.018, indexed in Pubmed: 16824980.

25. National Administrative Department of Statistics. Technical bulletin Vital statistics (births, non-fetal deaths and fetal deaths). https://www.dane.gov.co/files/investigaciones/poblacion/bt_estadisticasvitales_2015pre-2016pre-diciembre-2016.jpdf (20 October 2017).

26. Montoya JY, Yepes M, Navales E, et al. 46.6 Million dollars a year in the last year of life: the opportunity to incorporate palliative care for $1,8 \mathrm{M}$ of members of the health system in Colombia. X Congress of the Spanish Palliative Care Society. Madrid 2014.

27. Cheung MC, Earle CC, Rangrej J, et al. Impact of aggressive management and palliative care on cancer costs in the final month of life. Cancer. 2015; 121(18): 3307-3315, doi: 10.1002/cncr.29485, indexed in Pubmed: 26031241.

28. Brick A, Normand C. O'Hara S, Economic Evaluation of Palliative Care in Ireland, Trinity College, Dublin. Report prepared for The Atlantic Philanthropies, 2015.

29. Hugh T, Craft A, Davies C, et al. Funding the right care and support for everyone. Creating a fair and transparent funding system: the final report of the palliative care funding review. The Palliative Care Funding Review 2011. 
Emilio Herrera Molina ${ }^{1,2}$, Yaneth Marcela Montoya Jaramillo³, Zacarías Rodriguez ÁlvarezOssorio', Ana Carolina Gñomez García', Miguel Ángel Lucas Díaz', Irma María Echeverri Rincón Ingrid Muñoz Mayorga', María Nabal Vicuña ${ }^{4}$

${ }^{1}$ New Health Foundation, Sewilla, Hiszpania

${ }^{2}$ Keralty, Miami, Stany Zjednoczone

${ }^{3}$ EPS and Medicina prepagada Suramericana SA., Medellín, Kolumbia

${ }^{4}$ Zespół opieki paliatywnej Arnau de Villanova Hospital, Lleida, Hiszpania

\section{Koszty i wykorzystanie opieki zdrowotnej w ostatnim roku życia w Kolumbii — badanie retrospektywne}

Artykuł jest tłumaczeniem pracy: Herrera Molina E., Montoya Jaramillo Y.M., Rodriguez Álvarez-Ossorio Z., Gñomez García A.C., Lucas Díaz M.Á., Echeverri Rincón I.M., Muñoz Mayorga I., Nabal Vicuña M. Health care services utilization and cost in the last year of life in Colombia: a retrospective study. Palliat. Med. Pract. 2021, tom 15, nr 1: 9-17.

Należy cytować wersję pierwotną.

\section{Streszczenie}

Wstęp: Koszty opieki zdrowotnej pod koniec życia generują wysokie wydatki na zasoby opieki zdrowotnej. Wdrożenie zintegrowanych programów opieki paliatywnej jest efektywne kosztowo. Celem badania było przeprowadzenie analizy kosztów oraz wykorzystania zasobów opieki zdrowotnej w ostatnim roku życia przez pacjentów nieobjętych programem opieki paliatywnej.

Metody: Przeprowadzono opisowe, podłużne, retrospektywne badanie wśród pacjentów związanych z kolumbijską firmą ubezpieczeniową, którzy zmarli w 2013 roku w wyniku chorób wymagających i niewymagających opieki paliatywnej. Przyczyny śmierci pozyskano z oficjalnych aktów zgonu. Zastosowano strategię klasyfikacji McNamary i wsp., którą dostosowano do oceny usług otrzymanych przez pacjentów w ostatnim roku ich życia. Analizę kosztów przeprowadzono według schorzeń na różnych poziomach opieki nad chorymi.

Wyniki: W 2013 roku nastąpiły 3392 zgony (70\% pacjentów wymagających opieki paliatywnej oraz 30\% pacjentów niewymagających opieki paliatywnej). Łączny koszt opieki zdrowotnej to 47550155 USD. Pacjenci wymagający opieki paliatywnej generowali 84\% rocznych wydatków (wydatki roczne) (40 mln dolarów). Zidentyfikowano istotne różnice pomiędzy średnim kosztem opieki nad pacjentami wymagającymi i niewymagającymi opieki paliatywnej (16 878 USD vs. 7433 USD rocznie, $p<0,001$ ). Średni koszt na pacjenta w ciągu ostatnich trzech miesięcy jego życia stanowił 52\% wydatków ponoszonych w ostatnim roku życia (8 754 USD). Ostatni miesiąc życia to $25,6 \%$ kosztów ponoszonych w ciągu ostatniego roku życia (4 324 USD).

\section{Adres do korespondencji:}

Emilio Herrera Molina

New Health Foundation

Menendez Pelayo Av, 20. 4 41004 Sewilla, Hiszpania

e-mail: emilio.herrera@newhealthfoundation.org

Artykuł jest dostępny bezpłatnie na podstawie licencji Creative Common Attribution-Non-Commercial-No Derivatives 4.0 International (CC BY-NC-ND 4.0) umożliwiającej jego pobranie oraz udostępnianie pod warunkiem wskazania autorstwa i wydawcy. Niedopuszczalne jest wprowadzanie jakichkolwiek zmian lub wykorzystanie komercyjne bez zgody wydawcy. 
Wnioski: Koszty opieki w ostatnich trzech miesiącach życia pacjentów wymagających opieki paliatywnej generują ogromne wydatki na opiekę zdrowotną, związane głównie z kosztami opieki szpitalnej. Wdrożenie programu opieki paliatywnej może obniżać omawiane koszty świadczenia pomocy. Palliat Med Pract 2021; 15, 1: 18-27

Słowa kluczowe: opieka paliatywna, przyczyna zgonu, populacja, analiza kosztów i korzyści, modele

\section{Wstęp}

Bieżące trendy globalne sprawiają, że wzrasta długość życia, wiąże się to ze wzrostem częstości występowania chorób przewlekłych [1], które wywierają bezprecedensową presję na systemy opieki zdrowotnej $[2,3]$, niemożliwą do utrzymania w krótkim czasie. Prawie $70 \%$ osób umiera co roku z powodu zaawansowanych chorób nowotworowych (2500 przypadków na milion) lub chorób innych niż nowotworowe (4500 przypadków na milion) [4]. Jednakże, pomimo faktu, że na poziomie międzynarodowym zauważa się tę sytuację oraz pomimo istnienia polityk krajowych [5] oraz międzynarodowych [6, 7] w tym zakresie, opieką paliatywną objęte jest ledwie $14 \%$ populacji świata [8]. Brak modeli opieki paliatywnej skutkuje niezrównoważonym wzrostem kosztów opieki zdrowotnej oraz niską jakością opieki nad pacjentami [9] (niedostateczna kontrola objawów, niedostateczne uśmierzanie bólu [10], zgony szpitalne [11], brak komunikacji z rodzinami pacjentów oraz brak wsparcia dla rodzin [12]).

Jedne z najwyższych kosztów opieki zdrowotnej wiążą się z opieką nad chorymi na raka w ostatnim roku ich życia [13]. W Stanach Zjednoczonych koszt ten wynosi 205 miliardów dolarów (13\% całkowitych wydatków) [14], przy czym pacjenci chorujący przewlekle generują 57\% całkowitych kosztów (44 220 USD na osobę rocznie) [15]. W ostatnich sześciu miesiącach życia kumuluje się $40 \%$ całkowitych wydatków na opiekę zdrowotną [16], a wzrost ten jest największy w ciągu ostatnich 3 miesięcy życia pacjenta [17]. W przypadku nowotworów, koszt jednego pacjenta w regionie Hiszpanii wynosi do 12034 euro [18], natomiast same koszty opieki szpitalnej na osobę wynoszą 21840 USD w Kanadzie, 18500 USD w Staniach Zjednoczonych oraz 9342 USD w Anglii [19].

Słaby rozwój opieki paliatywnej wynika z braku świadomości decydentów i osób zarządzających wydatkami, które wynikają z niewdrożenia usług opieki paliatywnej. Pierwszym krokiem mającym na celu przyjęcie nowych, zintegrowanych i efektywnych kosztowo modeli opieki paliatywnej $[20,21]$, które mogłyby odpowiadać potrzebom osób u schyłku życia, jest analiza pomocy, otrzymywanej przez ludzi u schyłku życia nieobjętych programem opieki paliatywnej oraz kosztów dla ochrony zdrowia, jakie generuje tego rodzaju pomoc [22]. Badanie ma na celu identyfikację oraz pomiar kosztów, a także wykorzystania zasobów opieki zdrowotnej przez pacjentów powiązanych z kolumbijską firmą ubezpieczeniową (Suramericana S.A.) przed wdrożeniem programu opieki paliatywnej, w celu określenia potrzeby rozwoju programu opieki paliatywnej. W tym celu zastosowano metodę NewPalex® [23], aby osiągnąć doskonałość w zakresie opieki paliatywnej wewnątrz organizacji.

\section{Metody}

\section{Metodologia i populacja}

Przeprowadzono opisowe, podłużne, retrospektywne badanie mające na celu ocenę potrzeby wdrożenia programu opieki paliatywnej w firmie Suramericana S.A. Osoby, które zmarły w 2013 roku zostały zidentyfikowane oraz sklasyfikowane jako osoby wymagające i niewymagające opieki paliatywnej. Za osoby wymagające opieki paliatywnej uznano osoby cierpiące na zaawansowaną, nieuleczalną i postępującą chorobę, onkologiczną lub nieonkologiczną, niereagujące na określone leczenie, u których występowało postępujące pogorszenie stanu zdrowia, a przewidywana długość życia była ograniczona, oraz którym powinna była być świadczona pomoc z zakresu opieki paliatywnej i/lub osoby wpisujące się w kryteria McNamara [24]; identyfikowane z kryteriami ICD-10. Zakwalifikowane do grup: onkologia, przewlekła obturacyjna choroba płuc (POChP) oraz niewydolność serca, choroby neurodegeneracyjne (stwardnienie zanikowe boczne), choroba neuronów ruchowych (choroba Parkinsona, Huntingtona i Alzheimera), niewydolność nerek i inne (niewydolność wątroby oraz HIV-AIDS). W klasyfikacji uwzględniono również cukrzycę, ponieważ schorzenie to stanowi jedną z głównych przyczyn śmierci w Kolumbii [25].

Informacje o śmierci zostały pozyskane z bazy danych Suramericana S.A. Z oficjalnych aktów zgonu pozyskano również informacje o przyczynie śmierci - w 78\% przypadków — zarejestrowanej zgodnie z międzynarodową klasyfikacją ICD-10. Jeżeli akty zgonu nie były dostępne, w celu identyfikacji przyczyny zgonu analizie poddano przyjęcia do szpitala, wizyty ambulatoryjne u specjalistów oraz wyniki badań 
diagnostycznych wykonanych w ostatnim roku życia pacjentów w placówkach służby zdrowia.

\section{Zmienne}

Usługi klasyfikowano według miesięcy, poziomów opieki oraz standardowych usług:

1. Poziom III — opieka szpitalna:

- wysokie koszty związane z wysokokosztowymi zabiegami, przeszczepami i leczeniem nowotworów;

- zabiegi operacyjne;

- hospitalizacje;

- nagłe wypadki;

2. Poziom II — opieka ambulatoryjna:

- wizyty ambulatoryjne;

3. Poziom I - opieka w warunkach domowych:

- opieka w warunkach domowych;

4. Standardowe usługi: endoskopie, zaopatrzenie medyczne, leki, różne, badania diagnostyczne i leczenie.

Analiza objęła wszystkie interwencje zarejestrowane w systemie informatycznym ubezpieczyciela w ciągu ostatnich 12 miesięcy życia chorych. Do każdej interwencji przypisano koszty odpowiadające wartości kwoty zapłaconej w ramach danego działania. Wartości te przeliczono na dolary amerykańskie (kurs 1 USD = COP 1884,97$)$.

\section{Analiza statystyczna}

Analizę statystyczną przeprowadzono przy użyciu statystycznej bazy danych IBM SPSS ${ }^{\circledR}$ w celu uzyskania częstotliwości i odsetków oraz za pomocą testu t-Studenta w celu porównania średnich kosztów zwią- zanych z pacjentami wymagającymi oraz niewymagającymi do opieki paliatywnej.

\section{Wyniki}

W 2013 roku miały miejsce 3392 zgony, spośród których 70\% (2365 zgonów) dotyczyło pacjentów wymagających opieki paliatywnej, a 30\% (1027 zgonów) dotyczyło pacjentów niewymagających opieki paliatywnej.

\section{Pacjenci wymagający oraz niewymagający opieki paliatywnej}

Najczęstszą przyczyną śmierci wśród pacjentów wymagających opieki paliatywnej były nowotwory $(43,6 \%)$, następnie POChP $(22,6 \%)$ i cukrzyca $(13,1 \%)$ (tab. 1). Łączny koszt opieki u schyłku zycia wyniósł 47,5 miliona. Koszt związany z pacjentami wymagającymi opieki paliatywnej stanowił $84 \%$ całkowitego kosztu (40 milionów USD rocznie). Średni koszt na osobę w przypadku zgonu pacjenta wymagającego opieki paliatywnej był 2,3-krotnie wyższy niż w przypadku pacjentów niewymagających opieki paliatywnej (16 878 USD vs. 7433 USD na rok $p<0,001$ ) (tab. 1). Średnie koszty na osobę związane z nowotworami (20 820 USD), oraz HIV/niewydolnością wątroby (18 672 USD), niewydolnością nerek (18 626 USD) oraz niewydolnością serca (17 036 USD) były wyższe niż w całkowitej populacji zmarłych pacjentów (14 018 USD) (tab. 1).

Koszt związane z ostatnimi trzema miesiącami życia wyniósł 52\% (średni koszt 8754 USD) rocznych kosztów związanych z pacjentami wymagającymi opieki paliatywnej (tab. 2). Koszt opieki w ostatnim miesiącu

Tabela 1. Populacja osób zmarłych w 2013 ubezpieczonych w EPS Sura. Łączny koszt na osobę w ciągu ostatnich 12 miesięcy życia (osoby wymagające i niewymagające opieki paliatywnej)

\begin{tabular}{|c|c|c|c|c|}
\hline & Populacja & Odsetek & Łączny koszt (USD\$)/\% & Średni kosztu (USD\$) \\
\hline Liczba zgonów ogółem & 3392 & $100 \%$ & 47550155 USD & 14018 USD \\
\hline $\begin{array}{l}\text { Łączna liczba osób niewymagają- } \\
\text { cych opieki paliatywnej }\end{array}$ & 1027 & $30,3 \%$ & $7633642(16 \%)$ & $7433(*)$ \\
\hline $\begin{array}{l}\text { Łączna liczba osób wymagających } \\
\text { opieki paliatywnej }\end{array}$ & 2365 & $69,7 \%$ & 39916512 (84\%) & $16878\left(^{*}\right)$ \\
\hline Nowotwory & 1032 & $43,6 \%$ & $2486336(45,2 \%)$ & 20820 \\
\hline Inne (HIV, niewydolność wątroby) & 28 & $1,2 \%$ & $\$ 522,820(1.1 \%)$ & 18672 \\
\hline Kideny failure & 216 & $9.1 \%$ & $4,023,313(8.5 \%)$ & 18,626 \\
\hline Niewydolność serca & 166 & $7.0 \%$ & $2,827,970(5.9 \%)$ & 17,036 \\
\hline Cukrzyca & 309 & $13.1 \%$ & $4,018,491(8.5 \%)$ & 13,005 \\
\hline POChP & 534 & $22.6 \%$ & $6,536,101(13.7 \%)$ & 12,240 \\
\hline Choroby neurodegeneracyjne & 80 & $3.4 \%$ & $\$ 501,480(1.1 \%)$ & 6,269 \\
\hline
\end{tabular}

(*) Statystyka $t$-Studenta $\mathrm{p}=0,000$. Istnieją istotne różnice $\mathrm{w}$ średnich kosztach związanych z pacjentami wymagającymi i niewymagającymi opieki paliatywnej. 


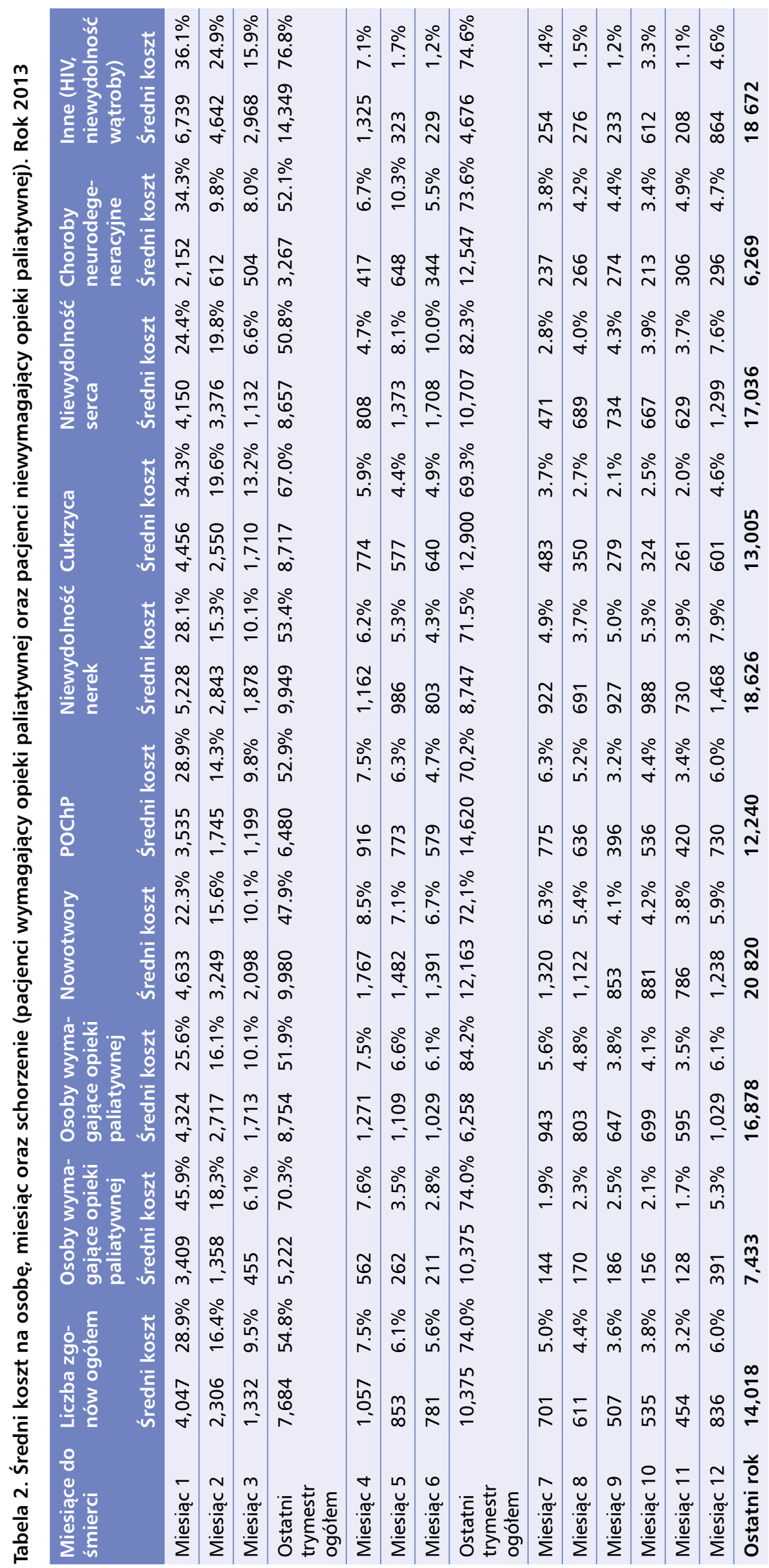



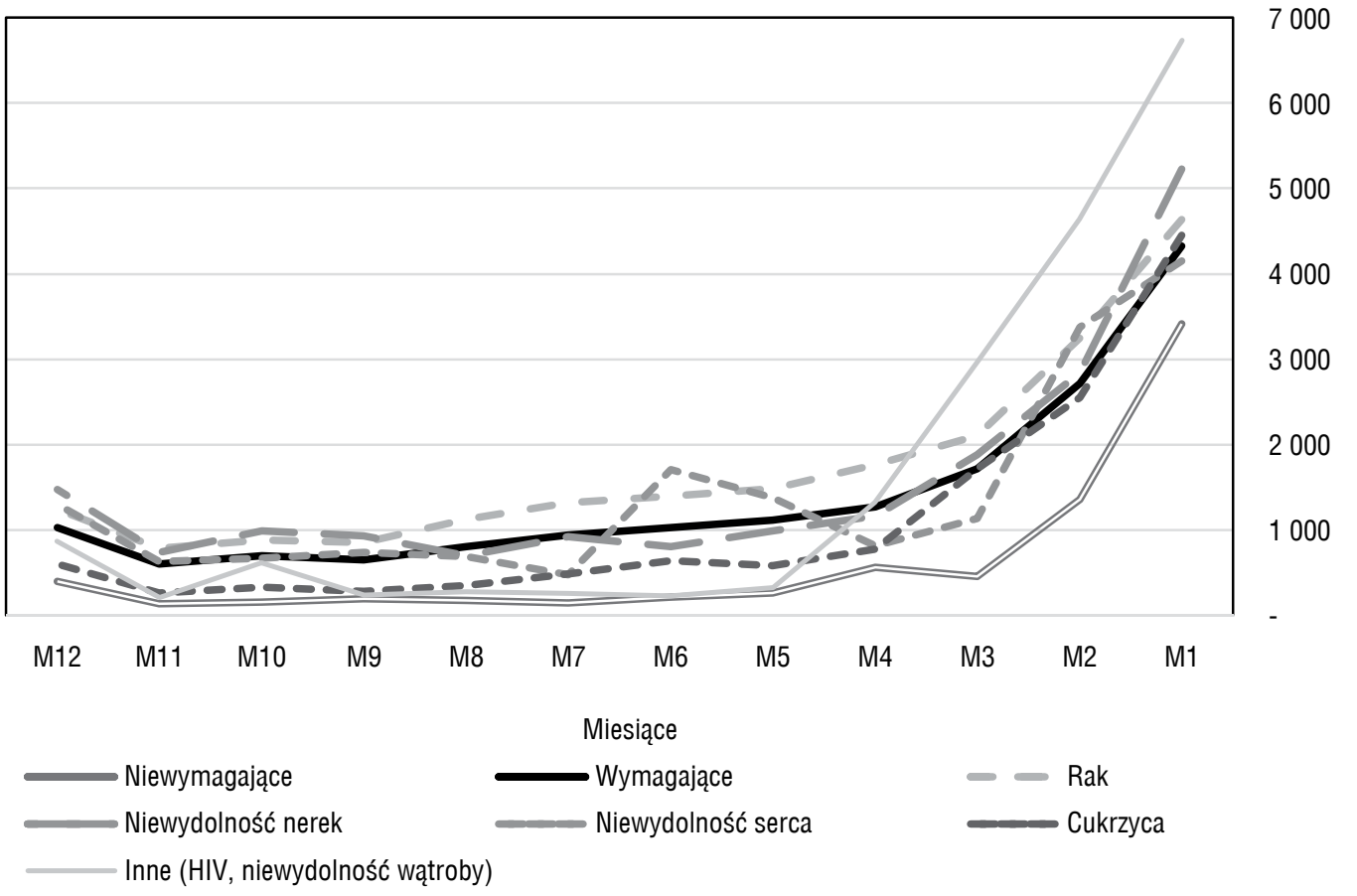

Rycina 1. Zmiany w średnich kosztach (USD\$) na osobę w ostatnim roku życia (pacjenci kwalifikujący się do opieki paliatywnej i pacjenci niekwalifikujący się do opieki paliatywnej) w 2013 roku

życia wyniósł był powyżej średniej u wszystkich pacjentów wymagających opieki paliatywnej (4 324 USD): HIV/niewydolność wątroby (6 739 USD), niewydolność nerek (5 228 USD), nowotwór (4 633 USD), cukrzyca (4 456 USD) oraz niewydolność serca (USD 4150 USD) (tab. 2). Zmiany w zakresie średnich kosztów na osobę w ostatnim roku życia pacjentów wymagających i niewymagających opieki paliatywnej przedstawiono na rycinie 1.

\section{Poziomy opieki}

Poziom III — koszt opieki szpitalnej stanowiła 56\% rocznego kosztu opieki nad pacjentami wymagającymi opieki paliatywnej, czyli 2-krotnie więcej niż w przypadku pacjentów niewymagających opieki paliatywnej (średni koszt roczny 9445 USD vs. 5401 USD) Szpitalna opieka nad pacjentem, wysokie koszty oraz zabiegi operacyjne stanowity $24,3 \%, 15,6 \%$ oraz $14,2 \%$ rocznych kosztów opieki nad pacjentami wymagającymi opieki paliatywnej (tab. 3). Zmiany w zakresie średnich kosztów na osobę u chorych wymagających opieki paliatywnej, z najwyższym kosztem w ostatnim roku życia przedstawiono na rycinie 2 .

Koszty opieki szpitalnej w ciągu ostatnich trzech miesięcy życia stanowiły $17 \%$ rocznego kosztu opieki nad pacjentami wymagającymi opieki paliatywnej. Średni koszt na osobę wynosił 436 USD w ostatnich trzech miesiącach życia oraz 1670 w ostatnim miesiącu życia. W ostatnim miesiącu życia opieka szpitalna odpowiadała za 38,6\% kosztów (średni koszt roczny 1670 USD); następne były zabiegi operacyjne (15,1\%), leki $(13,6 \%)$, wysokie koszty $(10,8 \%)$, różne $(5,0 \%)$, procedury diagnostyczne $(4,1 \%)$ (tab. 3$)$.

Na poziomie II — opieka ambulatoryjna — średni koszt na rok w przypadku zgonów pacjentów wymagających opieki paliatywnej był trzy razy wyższy niż w przypadku pacjentów, którzy nie wymagali takiej opieki (107 USD vs. 35 USD). Średni koszt roczny na poziomie I - opieka domowa - jest 3,5-krotnie wyższy w przypadku pacjentów wymagających opieki paliatywnej w stosunku do pacjentów, którzy niewymagających do takiej opieki (575 USD vs. 165 USD). Standardowe usługi stanowiły 40\% kosztów, natomiast leki stanowiły 23,3\% średniego rocznego kosztu (tab. 3).

\section{Dyskusja}

Koszty opieki u schyłku życia 2,5 miliona ubezpieczonych osób obliczono na 47,5 miliona USD, posiłkując się danymi z 2013 roku. Pacjenci wymagający opieki paliatywnej generują 84\% wydatków dochodzących do 40 milionów USD. Koszt ten jest związany z proporcjonalnym wzrostem w zakresie każdego $z$ różnych rodzajów usług $w$ ostatnim roku życia. Badanie wykazało, że brak programu opieki 


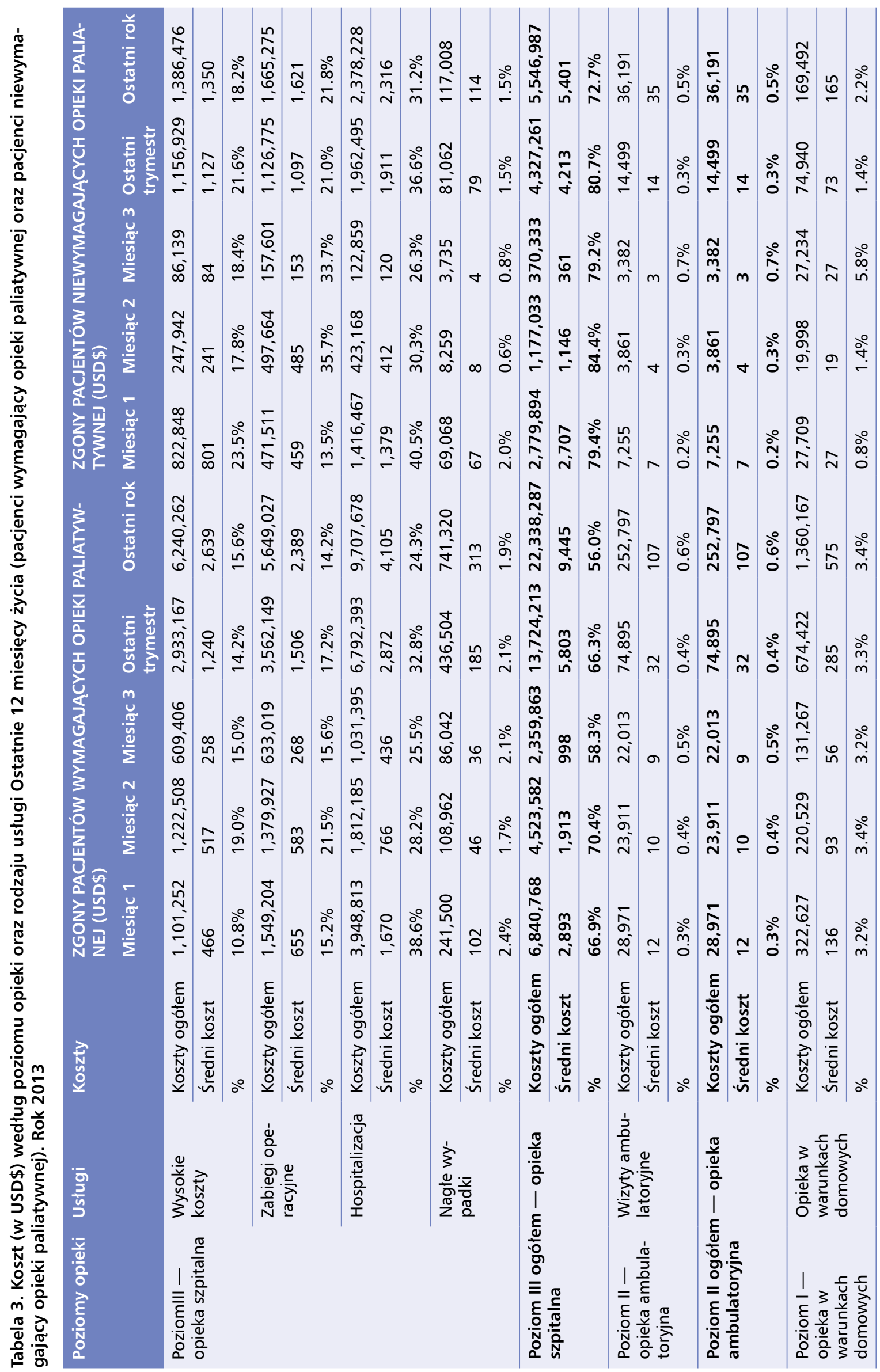




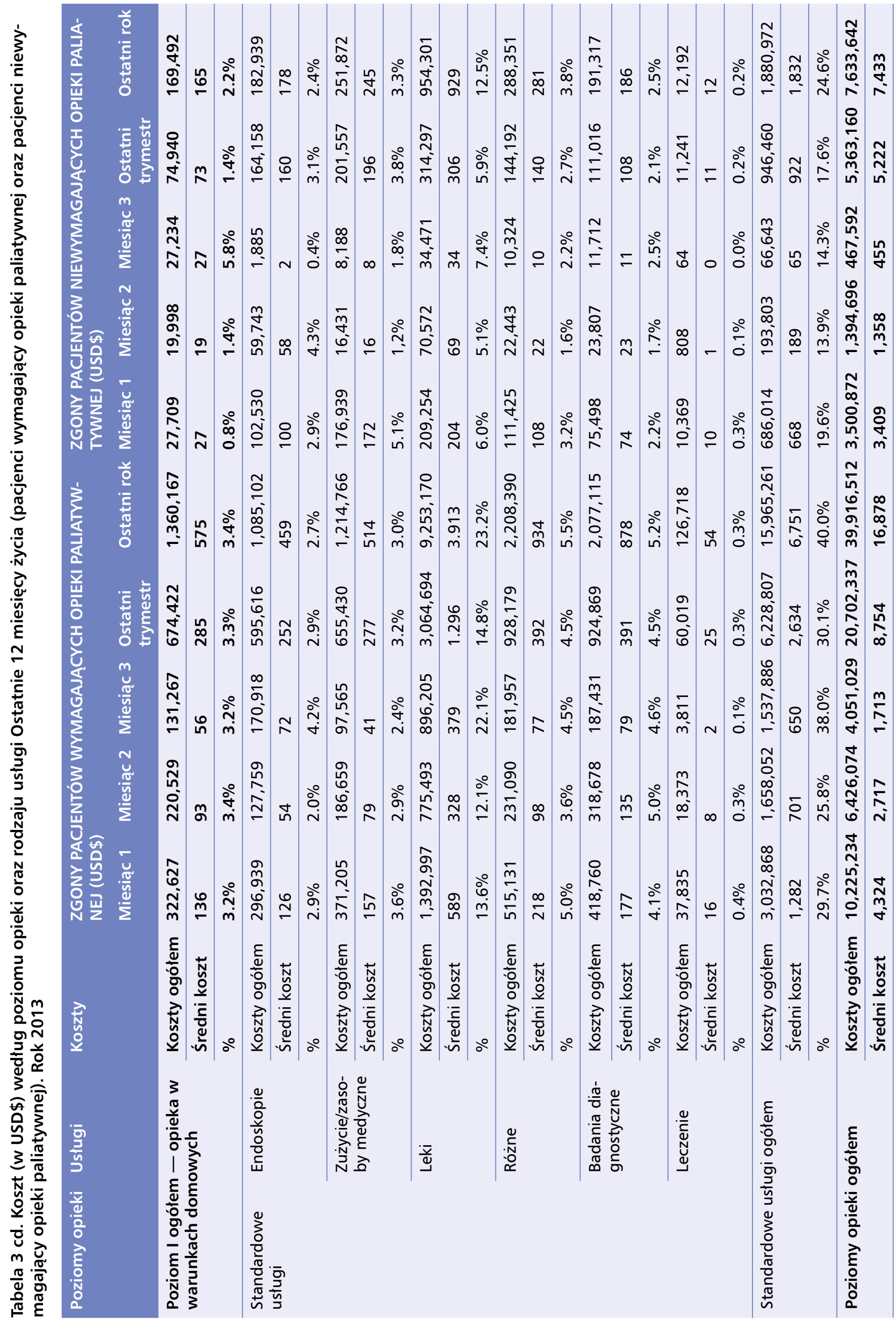




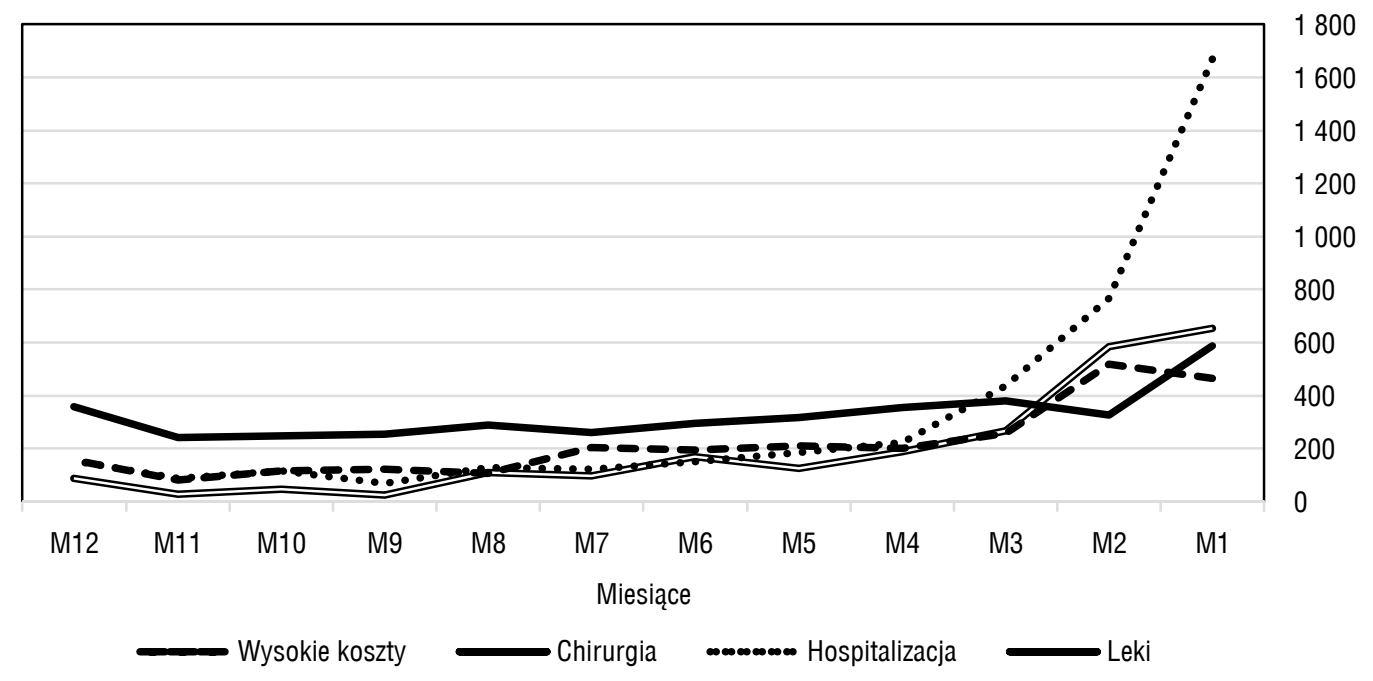

Rycina 2. Średni koszt (US\$) na osobę oraz schorzenia wymagające opieki paliatywnej; najwyższy koszt w ostatnim roku życia w 2013 roku

paliatywnej obejmującego pacjentów wymagających tego rodzaju opieki znacznie podnosi koszty w ostatnich trzech miesiącach życia, odpowiadając za $44 \%$ całkowitego kosztu związanego z opieką nad osobami, które zmarły (20 milionów USD/rok średni koszt roczny 8754 USD).

Koszty w ostatnim roku życia w Stanach Zjednoczonych obliczono na poziomie 205 miliardów USD [2] oraz 4,7 miliardów w Kanadzie [21]. W Kolumbii wydatki w trakcie ostatnich trzech miesięcy życia chorych wynoszą $50 \%$ całkowitych kosztów opieki w ostatnim roku życia [26]. Hospitalizacja w ostatnim miesiącu życia wiąże się z najwyższymi kosztami, które szacuje się na 67\% w Kanadzie [27], 59\% w Irlandii [28], 585 milionów GBP w Zjednoczonym Królestwie [29].

Ponadto należy podkreślić przydatność metodologii NewPalex ${ }^{\circledR}$ w zakresie identyfikacji pacjentów wymagających opieki paliatywnej w systemach informatycznych, dzięki wyszukiwaniu przyczyn śmierci oraz zabiegów przeprowadzonych w ostatnim roku życia chorych. Kody ICD-10 porównywane są z kryteriami McNamary i wsp. [24] dotyczącymi definiowania i oszacowywania populacji objętej opieką paliatywną. $\mathrm{Na}$ tej podstawie można ocenić koszty u schyłku życia na postawie systematycznego i powtarzalnego procesu. Można zatem przeprowadzić analizę stanu wyjściowego, która może stanowić pierwszy krok do wdrożenia programów opieki paliatywnej, z jasnymi celami i priorytetami wytyczającymi kierunek działań oraz oceniającymi wpływ ekonomiczny, kliniczny oraz wpływ na jakość usług.

Ten rodzaj analizy pozwala zarówno prywatnym, jak i publicznym ubezpieczycielom poznać koszty wynikające z niewdrożenia programu opieki paliatywnej. Brak tego typu ocen w sposób systematyczny przyczynił się do ograniczonego stopnia wdrażania programów opieki paliatywnej we współczesnych systemach opieki zdrowotnej pomimo ich wagi, a nawet programowego zaangażowania niektórych krajów w świadczenie tego rodzaju usług.

Opieka paliatywna daje możliwość świadczenia najbardziej ludzkiej i zintegrowanej opieki nad chorymi, która jednocześnie jest efektywna kosztowo. Po niniejszym badaniu w organizacji wdrożono program opieki paliatywnej zgodnie z metodologią NewPalex ${ }^{\circledR}$ w okresie od 2014 do 2018 roku. Przeprowadzono badanie porównawcze wśród pacjentów, którzy przystąpili oraz tych, którzy nie przystąpili do programu, a wyniki porównano z wynikami pierwszego badania, dochodząc do identycznych wniosków, jak te zawarte w niniejszym artykule, co pozwoliło na potwierdzenie wszystkich danych. Z tego też powodu po upływie 6 lat wnioski nadal są aktualne. Programy opieki paliatywnej powinny być systematycznie rozwijane przez organizacje opieki zdrowotnej, ponieważ pozwalają one zapewnić skuteczną, pełną współczucia oraz odpowiednią opiekę, jednocześnie przyczyniając się do zapewnienia równowagi w systemach ochrony zdrowia.

\section{Ograniczenia}

Mimo że badana populacja obejmuje wszystkie osoby, które zmarły, będąc objęte ubezpieczeniem firmy zrzeszającej około 2,5 miliona osób, osoby te należą do systemu ubezpieczeń składkowych. Dlatego 
też grupa ta nie stanowi dokładnej reprezentacji zbiorczej próby Kolumbijczyków, ponieważ wymagałoby to uwzględnienia w badaniu również osób objętych subwencjonowanym systemem ubezpieczeń. Podobnie, uogólniając wyniki, należy wykazać ostrożność również w zakresie wartości ilościowej, ponieważ odzwierciedlają one ceny uzgodnione między zakładem ubezpieczeń oraz świadczeniodawcami usług zdrowotnych, toteż mogą się różnić w przypadku innych zakładów ubezpieczeń lub w przypadku innych ustaleń umownych.

Trzecie ograniczenie ma związek z jakością wykorzystanych danych, ponieważ jest badaniem retrospektywnym, w którym $22 \%$ wszystkich przyczyn nie zostało zidentyfikowanych w rejestrach zgonów. Pewna liczba interwencji w zakresie opieki mogła zatem zostać pominięta, co może mieć istotne znaczenie dla wskazania przyczyn oraz późniejszych kosztów. Uważa się jednak, że jest to niezbędny punkt wyjścia do oceny zakresu programu, który będzie bardzo przydatny do przeprowadzenia perspektywicznego porównania kosztów w grupach chorych objętych lub nieobjętych zintegrowanym programem opieki paliatywnej.

\section{Wnioski}

Na podstawie badania można wnioskować, że ocena kosztów opieki u schyłku życia stanowi cenne narzędzie zarządzania, zarówno dla ubezpieczycieli, jak i osób zarządzających usługami oraz osób odpowiedzialnych za politykę zdrowotną. Jak wykazano, koszty te są wyższe w ostatnich miesiącach życia u pacjentów wymagających opieki paliatywnej, którzy nie otrzymują takiej opieki. Opieka nad chorym u schyłku życia nie obejmująca opieki paliatywnej ma znaczący wpływ na koszty ponoszone w ostatnich trzech miesiącach życia. Takie podejście generuje ogromną część rocznych całkowitych wydatków na ochronę zdrowia, w dużej mierze wynikających z opieki szpitalnej oraz agresywnych i kosztownych zabiegów.

\section{Deklaracja konfliktu interesów}

Autorzy deklarują brak konfliktu interesów

\section{Finansowanie}

To badanie nie zostało sfinansowane.

\section{Piśmiennictwo}

1. World Health Organization. Projections of mortality and causes of death, 2015 and 2030. Geneva 2015.

2. Aldridge MD, Kelley AS. The Myth Regarding the High Cost of End-of-Life Care. Am J Public Health. 2015; 105(12): 2411-2415, doi: 10.2105/AJPH.2015.302889, indexed in Pubmed: 26469646.
3. Martos F, Herrera E, Espín J, et al. Socioeconomic implications. In: Jadad AR, Cabrera A, Smith R, Lyons RF. editors). When people live with multiple chronic diseases: a collaborative aroach to an emerging global challenge. Granada: Andalusian School of Public Health. 2010: 211-227.

4. Franks PJ, Salisbury C, Bosanquet N, et al. The level of need for palliative care: a systematic review of the literature. Palliat Med. 2000; 14(2): 93-104, doi: 10.1191/026921600669997774, indexed in Pubmed: 10829143.

5. Congress of the republic. Consuelo Devis Saavedra Law: Official Gazette No. 49, 268. September 8, 2014. Constitutional Court. Law 1733 of 2014. Bogot 2014.

6. Recommendation Rec 24 of the Committee of Ministers of the member states on palliative care organization. Madrid: Quality Agency of the National Health System. Ministry of Health. 2003; 2005.

7. Schmidlin E, Oliver D. Palliative care as a human right: What has the Prague Charter achieved? Eur J Palliat Care. 2015; 22(3): 141-143.

8. World Health Organization. Palliative care: Key facts. http:// www.who.int/mediacentre/factsheets/fs402/es/ (9 September 2019).

9. The 2015 Quality of Death Index: Ranking palliative care across the world. The Economist Inteligence Unit Limited 2015. https://eiuperspectives.economist.com/sites/default/files/2015\%20EIU\%20Quality\%20of\%20Death\%20 Index\%200ct\%2029\%20FINAL.pdf/ (25 August 2019).

10. Solano JP, Gomes B, Higginson IJ. A comparison of symptom prevalence in far advanced cancer, AIDS, heart disease, chronic obstructive pulmonary disease and renal disease. J Pain Symptom Manage. 2006; 31(1): 58-69, doi: 10.1016/j.jpainsymman.2005.06.007, indexed in Pubmed: 16442483.

11. Khandelwal N, Curtis JR, Freedman VA, et al. How Often Is End-of-Life Care in the United States Inconsistent with Patients' Goals of Care? J Palliat Med. 2017; 20(12): 1400-1404, doi: 10.1089/jpm.2017.0065, indexed in Pubmed: 28665781.

12. Hudson PL, Aranda S, Kristjanson $\sqcup$. Meeting the supportive needs of family caregivers in palliative care: challenges for health professionals. J Palliat Med. 2004; 7(1): 19-25, doi: 10.1089/109662104322737214, indexed in Pubmed: 15008126.

13. Chastek B, Harley C, Kallich J, et al. Health care costs for patients with cancer at the end of life. J Oncol Pract. 2012; 8(6): 75s-80s, doi: 10.1200/JOP.2011.000469, indexed in Pubmed: 23598848.

14. Committee on Approaching Death: Addressing Key End of Life Issues; Institute of Medicine. Dying in America: Improving Quality and Honoring Individual Preferences Near the End of Life. Washington (DC): National Academies Press (US); 2015 Mar 19. Appendix E, Epidemiology of Serious Illness and High Utilization of Health Care. https://www. ncbi.nlm.nih.gov/books/NBK285684/ (20 August 2019).

15. Meier DE. Increased access to palliative care and hospice services: opportunities to improve value in health care. Milbank Q. 2011; 89(3): 343-380, doi: 10.1111/j. 1468-0009.2011.00632.x, indexed in Pubmed: 21933272.

16. May P, Garrido MM, Cassel JB, et al. Palliative Care Teams' Cost-Saving Effect Is Larger For Cancer Patients With Higher Numbers Of Comorbidities. Health Aff (Millwood). 2016; 35(1): 44-53, doi: 10.1377/hlthaff.2015.0752, indexed in Pubmed: 26733700.

17. Nuño-Solinís R, Herrera Molina E, Librada Flores $S$, et al. [Care costs and activity in the last three months of life of cancer patients who died in the Basque Country (Spain)]. 
Gac Sanit. 2017; 31(6): 524-530, doi: 10.1016/j.gaceta.2016.06.005, indexed in Pubmed: 27707518.

18. Librada S, Herrera E, Nuño R. Consumption of health resources and costs of end-of-life care for 18, 024 people killed by cancer in the Basque Country between 2008 and 2011. X Congress of the Spanish Palliative Care Society, Madrid 2014.

19. Bekelman JE, Halpern SD, Blankart CR, et al. International Consortium for End-of-Life Research (ICELR). Comparison of Site of Death, Health Care Utilization, and Hospital Expenditures for Patients Dying With Cancer in 7 Developed Countries. JAMA. 2016; 315(3): 272-283, doi: 10.1001/jama.2015.18603, indexed in Pubmed: 26784775.

20. Librada S, Herrera E, Nabal M. et al. Implementation models of cities and compassionate communities around people with advanced diseases and/or end of life situations: a systematic review. PROSPERO 2017: CRD42017068501. https:// www.crd.york.ac.uk/prospero/display_record.php?ID =CRD42017068501/ (24 July 2019).

21. Librada S, Herrera E, Pastrana T. Attention centered on the person at the end of life: Integrated socio-health care in palliative care. Actas de la coordinación sociosanitaria. 2015; $13: 67$.

22. Tanuseputro $\mathbf{P}$, Wodchis $W P$, Fowler $R$, et al. The health care cost of dying: a population-based retrospective cohort study of the last year of life in Ontario, Canada. PLoS One. 2015; 10(3): e0121759, doi: 10.1371/journal. pone.0121759, indexed in Pubmed: 25811195.
23. Herrera E, Librada S, Lucas MA, et al. The New Health Foundation: Transforming palliative care. Eur J Palliat Care. 2017; 24(3).

24. McNamara B, Rosenwax LK, Holman CD. A method for defining and estimating the palliative care population. J Pain Symptom Manage. 2006; 32(1): 5-12, doi: 10.1016/j.jpainsymman.2005.12.018, indexed in Pubmed: 16824980.

25. National Administrative Department of Statistics. Technical bulletin Vital statistics (births, non-fetal deaths and fetal deaths). https://www. dane.gov.co/files/investigaciones/poblacion/bt estadisticasvitales 2015pre-2016pre-diciembre-2016. pdf (20 October 2017).

26. Montoya JY, Yepes M, Navales E, et al. 46.6 Million dollars a year in the last year of life: the opportunity to incorporate palliative care for $1,8 \mathrm{M}$ of members of the health system in Colombia. X Congress of the Spanish Palliative Care Society. Madrid 2014.

27. Cheung MC, Earle CC, Rangrej J, et al. Impact of aggressive management and palliative care on cancer costs in the final month of life. Cancer. 2015; 121(18): 3307-3315, doi: 10.1002/cncr.29485, indexed in Pubmed: 26031241.

28. Brick A, Normand C. O'Hara S, Economic Evaluation of Palliative Care in Ireland, Trinity College, Dublin. Report prepared for The Atlantic Philanthropies, 2015.

29. Hugh T, Craft A, Davies C, et al. Funding the right care and support for everyone. Creating a fair and transparent funding system: the final report of the palliative care funding review. The Palliative Care Funding Review 2011. 